\title{
PENGARUH TINGKAT PENDIDIKAN FORMAL DAN PENGALAMAN KERJA TERHADAP KOMPENSASI PEGAWAI PADA KANTOR CAMAT MENDOYO
}

\author{
N.K.P Pebrianti ${ }^{1}$, Trianasari $^{2}$ \\ 1,2Jurusan Manajemen, Universitas Pendidikan Ganesha, Singaraja \\ e-mail: piskapebri33@gmail.com, nanatrianasari01@gmail.com
}

\begin{abstract}
Abstrak
Penelitian ini bertujuan untuk menguji pengaruh (1) tingkat pendidikan formal terhadap pengalaman kerja, (2) tingkat pendidikan formal terhadap kompensasi, (3) pengalaman kerja terhadap kompensasi, (4) peran pengalaman kerja memediasi tingkat pendidikan formal terhadap kompensasi. Penelitian menggunakan desain kuantitatif kausal, di mana data dianalisis menggunakan analisis jalur. Subjek penelitiannya adalah pegawai Kantor Camat Mendoyo, sementara objek penelitian ini adalah, tingkat pendidikan formal, pengalaman kerja, dan kompensasi. Populasi penelitian yang digunakan adalah seluruh pegawai yang berjumlah 30 orang sebagai responden. Hasil penelitian mengindikasikan tingkat pendidikan formal memengaruhi secarah positif dan signifikan pada pengalaman kerja; tingkat pendidikan formal mempengaruhi secara positif dan signifikanpada kompensasi; pengalaman kerja memengaruhi secara positif dan signifikan pada kompensasi dan pengalaman kerja memediasi pengaruh tingkat pendidikan formal terhadap kompensasi.
\end{abstract}

Kata Kunci: kuantitatif kausal, kompensasi, pengalaman kerja, tingkat pendidikan formal

\begin{abstract}
This study aimed to examine the effects of (1) the level of formal education on work experience, (2) the level of formal education on employee compensation, (3) work experience on employee compensation, (4) the mediating role of work experience on the inflence of the level of formal education on employee compensation. This research was a causal quantitative study in wich data were analyzed using path analysis. The subjects in this study were all employees of the Kantor Camat Mendoyo. The objects of this study were the level of formal education, work experience, andcompensation. The population of this study were 30 employees as respondents. The results obtained in this study indicate that the level of formal education has a positive and significant effect on work experience; the level of formal education has a positive and significant effect on compensation; work experience has a positive and significant effect on compensation and work experience mediates the effect of the level of formal education on compensation.
\end{abstract}

Keywords: causal quantitative, compensation, formal education level, work experience

\section{Pendahuluan}

Faktor penggerak utama seluruh kegiatan atau aktivitas sebuah organisasi adalah sumber daya manusia (SDM), hal ini termasuk aset yang dinilai penting sehingga wajib dikembangkan secara optimal. Tujuan organisasi akan tercapai apabila sumber daya mansuia (SDM) yang dimilikinya memiliki kemampuan untuk menggerakkan sumber daya lainnya. Hal ini sejalan dengan pendapat Simamora (2006) menyatakan bahwa SDM merupakanaset penting yang dimiliki oleh organisasi, dan SDM merupakan faktor penggerak berjalannya suatu sistem yang ada dalam organisasi. Oleh sebab itu, keberadaan SDM sangat dibutuhkan untuk mencapau tujuan organisasi. tanpa sumber daya manusia tujuan organisasi sulit berjalan dengan baik. Namun, SDM pada suatu organisasi harus dikembangkan dan dipersiapkan skillnya agar tujuan organisasi mudah untuk dicapai.

Manajemen SDM merupakan salah satu cara pengelolaan individu, anggota atau kelompok kerja, yaitu melalui peningkatan skill, pendayagunaan, pengembangan, evaluasi, serta pemberian reward atas kinerjanya. Hal ini dipertegas dengan pernyataan Marwansyah (2010) yang menjelaskan manajemen SDM merupakan cara mendayagunakan SDM pada suatu organisasi melali sistem fungsi-fungsi perencanaan SDM, penerimaan dan 
penyeleksian, pengembangan SDM, Perancangan karir, pemberian reward, keselamatan serta kesehatan kerja.

Salah satu tolok ukur keberhasilan organisasi adalah tingkat kesejahteraan yang diberikan perusahaan kepada para pegawai. Kesejahteraan pegawai dapat diukur melalui pemberian kompensasi. Besarnya kompensasi dipengaruhi oleh tingkat pendidikan formal dan pengalaman kerja pegawai. Hal tersebut dipertegas oleh pernyataan yang diungkapkan Hasibuan (2003) yang menyatakan apabila SDM memiliki jenjang pendidikan yang tinggi dan pengalaman bekerja lebih lama maka reward yang diberikan oleh sebuah organisasi kepadanya juga akan semakin tinggi, hal tersebut dilakukan sebagai bentuk penghargaan atas kemampuan dan keterampilannya yang dimilikinya. Hal ini juga didukung oleh studi empirik oleh Chahyadi (2011) yang mengungkapkan bahwa tingkat pendididikan dan pengalaman kerja memengaruhi secara positif pada kompensasi.

Kompensasi merupakan bentuk penghargaan perusahaan atas dedikasinya kepada perusahaan, yang mana sudah memberikan waktu, tenaga, dan idenyauntuk kemajuan perusahaannya, adapun penghargaan tersebut dapat berupa finansial, non finansial ataupun fasilitas. Pernyataan ini didukung oleh pernyataan Sihotang (2012) yang mengatakan kompensasi merupakanpemberian atau penghargaan kepada pegawai atau manajer yang dapat dalam bentuk finansial, non finansial ataupunproduk atau layanan. Pemberian kompensasi yang pantasdidasarkan pada hasil kinerja pegawai tersebut. Kinerja ialahoutput kerja yang optimal baik secara kualitas maupun kuantitas yang telah dikerjakan oleh pegawai dalam menjalankan pekerjaannya dengan disertai rasa tanggungjawab (Mangkunegara, 2005).

Berdasarkan penelitian di 3 kantor camat Kabupaten Jembrana, yakni Kantor Camat Negara, Jembrana dan Mendoyo, ditemukan permasalahan mengenai kompensasi pada Kantor Camat mendoyo. Diduga kompensasi yang diterima pegawai belum optimal, maka dari itu penulis memokuskan penelitian pada Kantor Camat Mendoyo.

Berdasarkan Penelitian yang dilakukan pada Kantor Camat Mendoyo diduga terdapat permasalahan mengenai pemberian kompensasi, seperti gaji yang belum sesuai dengan UMK (Upah Minimum Kabupaten) kabupaten Jembrana. Pemberian kompensasi diduga dipengaruhi oleh tingkat pendidikan formal dan pengalaman kerja. Kantor Camat Mendoyo merupakan instansi pemerintahan yang memiliki tugas utamamenjalankan kewenangan pemerintahan dari Bupati, dan berfungsi sebagai lembaga pemerintahan yang menangani sebagian perkara otonomi daerah dan juga melaksanakan tugas umum pemerintahan. Kantor Camat Mendoyo terletak di Desa Pergung, Kecamatan Mendoyo, Kabupaten Jembrana. Kantor Camat Mendoyo memiliki jumlah pegawai 30 orang.

Dari observasi yang dilakukan pada pegawai Kantor Camat Mendoyo pemberian kompensasi pada umumnya masih di bawah Upah Minimum Kabupaten (UMK). Gaji yang diterima pegawai berkisar Rp. 1.165 .000 hingga Rp. 3.300.000. Fakta yang terjadi di lapangan, gaji yang diterima pegawai di atas UMK saja masih dikeluhkan pada pegawai, mulai dari permasalah lebih besar pengeluaran daripada gaji yang didapat karena mempunyai tanggungan yang besar, sampai dengan gaji yang sudah dipotong hutang. Selain gaji yang didapat, pegawai juga mengeluhkan fasilitas yang didapat, mulai dari bangunan kantor, ruang kerja yang kurang nyaman dan parkir kendaraan diduga belum optimal.

Pemberian kompensasi yang kurang diduga karena tingkat pendidikan pegawai pada Kantor Camat Mendoyo masih rendah. Jika pegawai mempunyai wawasan yang luas maka dalam melaksanakan tugasnya tidak terlalu sulit. Pendidikan merupakan pembelajaran yang disiapkan untuk meningkatkan tugas dan pekerjaan dimasa yang akan datang. Hal ini didukung pernyataan Atmodiwirio (2002) yang mengungkapkan pendidikan merupakan salah satu media untuk mempersiapkan dan meningkatkan kemampuan individu agar mampu mengemban amanah atau tanggung jawab yang diberikan kepadanya yang berhubungan dengan tugas atau pekerjaannya di masa yang akan datang. Tingkat pendidikan formal pegawai di Kantor Camat Mendoyo sebagian besar hanya lulusan SMA yang memiliki persentase $56 \%$, itu mengakibatkan kinerja dari instansi menjadi kurang, dikarenakan tingkat pendidikan pegawai masih rendah, yang mengakibatkan kurangnya keahlian pegawai dalam 
menjalankan tugas. Selain tingkat pendidikan formal, pengalaman kerja pegawai juga sangat penting. Pengalaman kerja dapat diukur dari berapa lama/masa kerja pegawai dan keahlian apa saja yang telah ia dapatkan.

Masa kerja pegawai dapat diukur sekurang kurangnya minimal 3 tahun agar dikatakan berpengalaman, Wiratama (2015). Siagian (2007) mengungkapkan bahwa pengalaman kerja seseorang didasarkan pada seberapa lama pekerja bekerja di bidangnya, jenis pekerjaan yang telah dikerjakan, dan seberapa lama periode kerjanya pada tiap-tiap pekerjaan tersebut. Pengalaman kerja pegawai juga dihitung dari berapa kali mereka berganti jabatan dan keterampilan apa saja yang telah mereka kuasai. Bahkan dari informasi, terdapat pegawai yang belum menguasai peralatan dan teknologi seperti pengaplikasian komputer. Masa kerja yang tidak lama mengakibatkan pegawai kurang memiliki keterampilan dan pengetahuan yang mengakibatkan mereka tidak memahami tugas yang diberikan. Semakin lama periode kerja pegawai, maka semakin meningkat kinerjanya, hal ini menyebabkan kompensasi yang terima pegawai akan meningkat.

Dari penguraian latar belakang tersebut, maka peneliti berinisiatif untuk melaksanakan penelitian tentang tingkat pendidikan formal, pengalaman kerja serta kompensasi pegawai di Kantor Camat Mendoyo. Adapun rumusan masalah penelitian yakni: (1) Apakah ada pengaruh tingkat pendidikan terhadap pengalaman kerja di Kantor Camat Mendoyo? (2) Apakah ada pengaruh tingkat pendidikan formal terhadap kompensasi pegawai di Kantor Camat Mendoyo? (3) Apakah ada pengaruh pengalaman kerja terhadap kompensasi pegawai di Kantor Camat Mendoyo?(4) Apakah pengalaman kerja memediasi tingkat pendidikan formal pada kompensasi pegawai di Kantor Camat Mendoyo?

Tujuan penelitian ini yakni meliputi: (1) Untuk menguji pengaruh tingkat pendidikan formal terhadap pengalaman kerja pada Kantor Camat Mendoyo. (2) Untuk menguji pengaruh tingkat pendidikan formal terhadap kompensasi pegawai pada Kantor Camat Mendoyo. (3) Untuk menguji pengaruh pengalaman kerja terhadap kompensasi pegawai pada Kantor Camat Mendoyo. (4) Untuk menguji peran pengalaman kerja memediasi pengaruh tingkat pendidikan formal terhadap kompensasi pegawai pada Kantor Camat Mendoyo.

Hasil penelitian diharapkan memberikan manfaat bagi pihak yang membutuhkan, baik secara teoritis maupun praktis, secara rinci dijelaskan berikut ini: (1) Manfaat Teoritis, yakni memberikan sumber rujukan empirik dan memperdalam pemahaman khasanah keilmuanyang berkaitan dengan Manajemen SDM. (2) Manfaat Praktis, yakni memberikan informasi kepada Kepala Camat Mendoyo dan seluruh pegawai kantor Camat Mendoyo akan pengaruh dari tingkat pendidikan formal dan pengalaman kerja untuk meningkatkan kompensasi, sehingga dapat dijadikan acuan dalam menerapkan kebijakan terkait kinerja pegawai.

\section{Metode}

Penelitian ini termasuk penelitian kuantitatif kausal, yang mana data dalam bentuk angka dianalisis statistik yang ditujukan untuk menilai hubungan antar variabel. Sugiyono (2009) mengungkapkan desain penelitian kuantitatif kausal dilakukan dengan cara sebagai berikut: (a) perumusan masalah, (b) penyusunan landasan teori, (d) pelaksanaan penelitian, (e) pengumpulandan analisa data, serta (f) penyusunan laporan dan penarikan kesimpulan. Penelitian ini menggunakan variabel bebas tingkat pendidikan formal $\left(X_{1}\right)$, pengalaman kerja $\left(\mathrm{X}_{2}\right)$ adapun variabel terikatnya yaitu kompensasi $(\mathrm{Y})$.

Subjek dalam penelitian ini adalah pegawai Kantor Camat Mendoyo. Objek penelitian ini adalah Tingkat pendidikan formal $\left(\mathrm{X}_{1}\right)$, Pengalaman kerja $\left(\mathrm{X}_{2}\right)$, Kompensasi $(\mathrm{Y})$. Penelitian ini menggunakan penelitian populasi, karena semua populasi digunakan sebagai responden yang memiliki karakteristik yang sama. Populasi yang digunakan yaitu seluruh pegawai Kantor Camat Mendoyo sebanyak 30 responden. Jenis data yang digunakan yakni data kuantitatif. Data kuantitatif dalam bentuk skor jawaban responden tentang tingkat pendidikan formal, pengalaman kerja, dan kompensasi di Kantor Camat Mendoyo.Penelitian ini menggunakan data primer, yang berasal dari jawaban responden. Kuisioner yang telah 
disebarkan kepada pegawai, selanjutnya dikumpulkan, dipilah, dan dikelompokkan berdasarkan hasil jawaban yang diberikan oleh para responden tersebut.

Analisis data dilaksanakan dengan menggunakan teknik analisis jalur. Model analisis ini berfungsi untuk menganalisa pola hubungan antar variabel.Analisa data menggunakan analisis ini akan diketahui pengaruh variabel bebas terhadap variabel terikatnya (Riduwan dan Kuncoro, 2008). Teknik tersebut digunakan sebab dimungkinkan terjadinya hubungan kausal antar variabel bebas yang meliputi: tingkat pendidikan formal $\left(X_{1}\right)$ terhadap pengalaman kerja $\left(\mathrm{X}_{2}\right)$, sehingga terjadi hubungan tidak langsung antara tingkat pendidikan formal $\left(\mathrm{X}_{1}\right)$ kompensasi $(\mathrm{Y})$ dan pengalaman kerja $\left(\mathrm{X}_{2}\right)$.

\section{Hasil dan Pembahasan}

Pengaruh masing-masing variabel terhadap kompensasi pegawai Pada Kantor Camat Mendoyo dapat dijelaskan pada Gambar1.

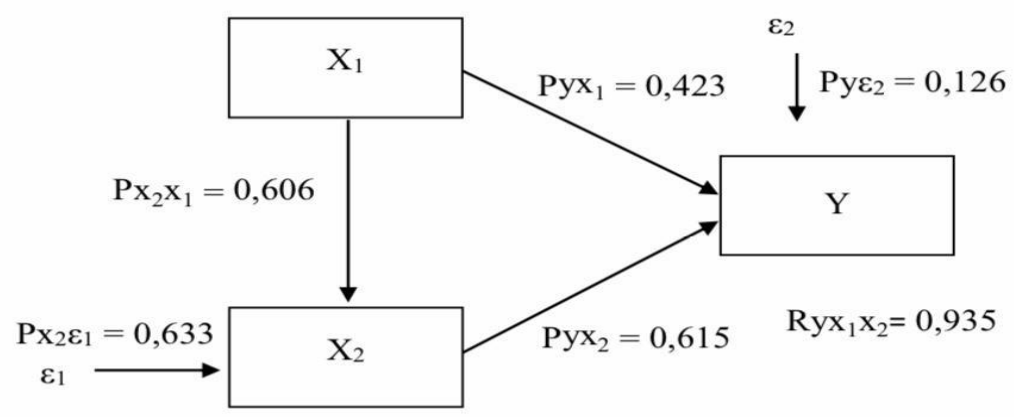

Gambar 1

Struktur Pengaruh Variabel Tingkat Pendidikan Formal dan Pengalaman Kerja terhadap Kompensasi Pegawai Pada kantor Camat Mendoyo

Nilai sumbangan pengaruh langsung dan tidak langsung dari variabel tingkat pendidikan formal dan pengalaman kerja pada kompensasi pegawai di Kantor Camat Mendoyo disajikan pada Tabel 1.1.

Tabel 1 Sumbangan Pengaruh Variabel Tingkat Pendidikan Formal dan Pengalaman Kerja terhadap Kompensasi Pegawai Pada Kantor Camat Mendoyo

\begin{tabular}{lcc}
\hline \multicolumn{1}{c}{ Keterangan } & Besar Sumbangan & Persentase \\
\hline Besar pengaruh langsung $X_{1}$ terhadap $Y$ & 0,179 & $17,9 \%$ \\
Besar pengaruh tidak langsung $X_{1}$ terhadap $Y$ & 0,372 & $37,2 \%$ \\
melalui $X_{2}$ & & \\
Besar pengaruh total $X_{1}$ terhadap $Y$ & 0,551 & $55,1 \%$ \\
Besar pengaruh total $X_{2}$ terhadap $Y$ & 0,379 & $37,9 \%$ \\
Besar pengaruh total $X_{1}$ dan $X_{2}$ terhadap $Y$ & 0,874 & $87,4 \%$ \\
Besar pengaruh lain $X_{1}$ dan $X_{2}$ terhadap $Y$ & 0,126 & $12,6 \%$ \\
Total & 1,000 & $100,0 \%$ \\
\hline
\end{tabular}

Berdasarkan hasil penelitian uji statistic path analysis, ada peran pengalaman kerja memediasi pengaruh tingkat pendidikan formal terhadap kompensas pegawai pada Kantor Camat Mendoyo. Tingkat pendidikan formal memengaruhi pengalaman kerja pegawai, nilai sumbangannya yakni 36,7\%. Tingkat pendidikan formal memengaruhi kompensasi pegawai, nilai sumbangannya yakni $17,9 \%$. Pengalaman kerja memengaruhi kompensasi pegawai, nilai sumbangannya yakni $37,9 \%$. Tingkat pendidikan formal dan pengalaman kerja 
mempengaruhi kompensasi pegawai, nilai sumbangannya yakni $87,4 \%$. Adapun faktor lain yang serta memengaruhi pengalaman kerja, nilai sumbangannya yakni $63,3 \%$, dan faktor lain yang memengaruhi kompensasi pegawai, nilai sumbangannya yakni $12,6 \%$.

Mengacu pada (Hair et al, 2013 dalam sholihin 2014), berdasarkan hasil uji mediasi melalui penghitungan Nilai VAF (Variance Accounted For), formulanya yaitu berikut ini.

$$
\begin{aligned}
\text { VAF } & =\frac{\text { Pengaruh Tidak Langsung }}{\text { Pengaruh Langsung }+ \text { Pengaruh Tidak Langsung }} \\
\text { VAF } & =\frac{0,372}{0,179+0,372} \\
\text { VAF } & =0,687 \text { atau 68,7\% }
\end{aligned}
$$

Hasil nilai VAF dapat menjelaskan kemampuan pengalaman kerja dalam memediasi secara parsial atau sebaliknya tidak dapat memediasi. Apabila diperoleh nilai VAF $>80 \%$ maka dapat dikatakan bahwa pengalaman kerja mampu memediasi secara penuh. Apabila nilai VAF berada diantara20\% hingga 80\% maka pengalaman kerja dapat memediasi secara parsial,dan apabila nilai VAF $<20 \%$ maka pengalaman kerja dinyatakan tidak dapat memediasi. Dari hasil perhitungan VAF, didapatkan hasil sebesar 0,687 atau $68,7 \%$ bahwa pengalaman kerja memediasi pengaruh tingkat pendidikan formal terhadap kompensasi pegawai.

Berdasarkan penelitian yang telah dilakukan bahwa tingkat pendidikan formal memengaruhi secara positif pada pengalaman kerja pegawai Kantor Camat Mendoyo. Hasil ini didukung pernyataan Hasibuan (2008) yang menjelaskan bahwa semakin tinggi pendidikan pegawai maka pegawai tersebut semakin cakap dan terampil dalam mengerjakan pekerjaannya, sehingga pengalaman kerjanya juga akan mengalami peningkatan. Dilihat pada tingkat pendidikan formal pegawai pada Kantor Camat Mendoyo, pada umumnya hanya lulusan SMA, maka dari itu pengalaman kerja yang dimilki rendah. Pegawai yang lulusan SMA kurang dapat memahami tugas dan pekerjaan yang diberikan. Pengetahuan dan keterampilan menjadi ukuran pengalaman kerja yang dimiliki pegawai. Hal tersebut juga didukung oleh pernyataan Wirawan (2019), yang menjelaskan tingkat pendidikan mempengaruhi secara positif pada pengalaman kerja.

Hasil analisis berikutnya mengindikasikan bahwa tingkat pendidikan formall memengaruhi secara positif pada kompensasi pegawaidi Kantor Camat Mendoyo. Hasill penelitian ini mendukung pendapat Tohardi (2002), yang menjelaskan bahwa penghitungan kompensasi didasarkan pada penilaian hasil kerja, yang artinya pemberian kompensasi akan didasarkan pada kelayakan dan keadilan. Tingkat pendidikan pegawai pada Kantor Camat Mendoyo pada umumnya lulusan SMA dan kebanyakan menjadi pegawai kontrak. Pegawai kontrak hanya mendapatkan gaji dibawah UMK. Artinya jika pegawai mempunyai tingkat pendidikan yang tinggi maka kompensasi yang diterima lebih besar. Jika mempunyai pendidikan tinggi dan pengetahuan yang luas, mereka dapat mencapai posisi jabatan yang lebih tinggi, karena semakin tinggi jabatan seseorang makasemakin besar kompensasi didapatkannya. Hasiltersebut sejalan dengan pernyataan Indrayati (2019), pendidikan mempengaruhi pemberian kompensasi.

Hasil analisis selanjutnya menujukkan bahwa pengalaman kerja mempengaruhi secara positif pada kompensasi pegawai di Kantor Camat Mendoyo. Temuan sejalan teori Hasibuan (2007), yang menyatakan bahwa tingkat pendidikan dan lamanya pengalaman kerja dapat mempengaruhi tingkat kompensasi. Lama masa kerja pegawai pada Kantor Camat Mendoyo paling rendah adalah 1 sampai dengan 1,5 tahun. Menurut Wiratama (2015) masa kerja pegawai dapat diukur sekurang-kurangnya minimal 3 tahun agar dikatakan berpengalaman. Masa kerja yang rendah mengakibatkan kurangnya pemahaman tentang tugas yang diberikan oleh atasan sehingga hasil pekerjaan tidak sesuai dengan target kinerja organisasi, maka kompensasi berupa insentif yang didapat belum optimal. Penelitian ini konsisten dengan kajian emperik yang dilakukan oleh Farish (2016) dan Dash (2017) yang mengungkapkan bahwa pengalaman kerja mempengaruhi kompensasi. 
Hasil peneltian selanjutnya menjukkan bahwa pengalaman kerja memediasi pengaruh tingkat pendidikan formal terhadap kompensasi pegawai pada Kantor Camat mendoyo. Hal tersebut ditunjukkan dengan nilai VAF $=0,687$ atau $68,7 \%$. Pendidikan yang dimiliki pegawai dapat memengaruhi pemberian kompensasi, hal ini sangat erat kaitannya dengan pengalaman kerja. Mempunyai kompetensi dan keahlian yang yang baik akan meningkatkan kinerja, jika kinerja baik perusahaan tak segan meningkatkan kompensasi yang diberikan. Sejalan dengan teori Manulang (1984) yaitu pengalaman kerja merupakan penambahan wawasan dan keterampilan untuk menyelesaikan tugas yang akan diembannya, yang artinya bisa didapatkan melalui jenjang pendidikan. Penelitian ini mendukung pernyataan Chahyadi (2011), yang menjelaskan bahwa pendidikan dan pengalaman kerja mempengaruhi kompensasi.

\section{Simpulan dan Saran}

Berlandaskan hasil dan pembahasan diatas, maka kesimpulan dari penelitian ini yaitu: (1) Tingkat pendidikan formal memengaruhi secara positif dan signifikan pada pengalaman kerja di Kantor Camat Mendoyo. Hal tersebut mengindikasikan bahwa semakin tinggi tingkat pendidikan formal pegawai maka pengalaman kerja akan meningkat, karena pengetahuan semakin pegawai semakin luas. (2) Tingkat pendidikan formal memengaruhi secara positif dan signifikan pada kompensasi pegawai di Kantor Camat Mendoyo. Hal tersebut mengindikasikan bawa semakin tinggi tingkat pendidikan pegawai maka kompensasi yang diterima akan semakin meningkat. (3) Pengalaman kerja mempengaruhi secara positif dan signifikan pada kompensasi pegawai di Kantor Camat Mendoyo. Hal tersebut mengindikasikan bahwa semakin lama pengalaman kerja seorang pegawai, maka dalam mengerjakan suatu pekerjaan akan semakin mudah, hal ini menjadikan kompensasi yang diterima semakin meningkat. (4) Pengalaman kerja mampu memediasi tingkat pendidikan formal secara positif dan signifikan pada kompensasi pegawai di Kantor Camat Mendoyo. Hal tersebut mengindikasikan bahwa kompensasi sangat terkait dengan tingkat pedidikan formal dan pengalaman kerja pegawai pada Kantor Camat Mendoyo.

Berlandaskan pemaparan di atas, maka peneliti mengajukan beberapa saran, yaitu: (1) Bagi pihak manajemen Kantor Camat Mendoyo, agar lebih memerhatikan tingkat pendidikan formal dan pengalaman kerja dalam mempertimbangkan pemberian kompensasi pegawai. Hal tersebut karena tingkat pendidikan formal bertujuan untuk mengembangkan pengetahuan dan keterampilan kerja, sehingga pegawai mampu meningkatkan pengalaman kerja dalam rangka mendukung tercapainya kompensasi pegawai yang tinggi. (2) Bagi peneliti selanjutnya yang akan melaksanakan penelitian terkait tingkat pendidikan formal, pengalaman kerja, dan kompensasi pegawai makasebaiknya menambah jumlah sampel agar hasil penelitiannya lebih akurat dan handal. Selain itu, periset dapat menambahkan variabel lain yang diduga mampu memengaruhi kompensasi pegawai, misalnya beban kerja dan produktivitas kerja.

\section{Daftar Pustaka}

Atmodiwirio. 2002. Manajemen Pelatihan. Jakarta: PT Pustaka Buletin Produktivitas Ed2.

Chahyadi, C. 2011. The Role of Education and Experience in CFO Career and Compensation, Journal of Accounting and Finance. Journal of Accounting and Finance, 11.

Dash, Mihir. 2017. The Relationship Between Work Experience And Employee Compensation: A Case Study Of The Indian It Industry. Journal Of Applied Management And Investment, Vol.6, No.1.

Farish, Raflika. 2016. Pengaruh Pendidikan dan Pengalaman Kerja Terhadap Produktivitas Karyawan. E-journal Bisma Universitas Pendidikan Ganesha, Vol.4.

Hasibuan. 2003. Manajemen Sumber Daya Manusia. Jakarta: PT Bumi Aksara. 
Hasibuan. 2007. Manajemen Sumber Daya Manusia. Jakarta: PT Bumi Aksara.

Hasibuan. 2008. Manajemen Dasar, Pengertian Dan Masalah. Jakarta: PT Bumi Aksara.

Indrayati, lin. dkk. 2019. Faktor-Faktor Yang Mempengaruhi Pemberian Kompensasi Pada Pegawai Kantor Kecamatan Nongsa. DIMENSI, Vol.8, No.1.

Kuncoro, A. dan E. R. 2008. Cara Menggunakan dan Memakai Analisis Jalur. Bandung: Alfabeta.

Mangkunegara, A. A. A. P. 2005. Manajemen Sumber Daya Manusia Perusahaan. Bandung: PT Remaja Rosdakarya.

Manulang. 1984. Manajemen Personalia. Jakarta: Ghalia Indonesia.

Marwansyah. 2010. Perilaku Organisasi. Bandung: Alfabeta.

Siagian, S. 2007. Fungsi-Fungsi Manajerial. Jakarta: Bumi Aksara.

Sihotang. 2007. Manajemen Sumber Daya Manusia. Jakarta: PT Pradnya Mita.

Simamora, H. 2006. Manajemen Sumber Daya Manusia. Yogyakarta: Sekolah Tinggi IImu Ekonomi YKPN.

Solihin, Mahfud dan Ratmono, Dwi. 2013. Analisis SEM-PLS dengan WarpPPL 3.0. Yogyakarta: ANDI.

Sugiyono. 2009. Metodelogi Penelitian Bisnis. Bandung: Alfabeta.

Tohardi. 2002. Pemahaman Praktis Sumber daya Manusia. Bandung: Mandar Maju.

Wirawan, Ketut Edy. 2019. Pengaruh Tingkat Pendidikan dan Pengalaman Kerja Terhadap Kinerja Karyawan. Vol 5, No 1.

Wiratama, Jefferson William 2015. Pengaruh Independensi, Pengalaman Kerja, Due Professional Care dan Akuntabilitas Terhadap Kualitas Audit. E-jurnal Akuntansi Universitas Udayana 10.1. 